GHÂNCARAN: JURNAL PENDIDIKAN
$\begin{aligned} & \text { BAHASA DAN SASTRA INDONESIA } \\ & \frac{\text { http://ejournal.iainmadura.ac.id/index.php/ghancaran }}{\text { E-ISSN: 2715-9132 ; P-ISSN: } 2714-8955} \\ & \text { DOI 10.19105/ghancaran.v3i2.4705 }\end{aligned}$

\title{
Representasi Nilai Kenabian dalam Antologi Puisi Rumah-Mu Tumbuh di Hati Kami Karya Sosiawan Leak: Tinjauan Sastra Profetik
}

\author{
Agus Tika Dwi Savira*, Siti Isnaniah** \\ * Tadris Bahasa Indonesia, UIN Raden Mas Said Surakarta \\ ** Tadris Bahasa Indonesia, UIN Raden Mas Said Surakarta \\ Alamat surel: agustikadwi1234@gmail.com; sisnaniah7@gmail.com
}

\begin{tabular}{l}
\hline \hline \\
\hline Keywords: \\
PropheticValue; \\
Indonesian \\
Languageand \\
Literature Learning; \\
Poetry Anthology.
\end{tabular}

\section{Abstract}

This research was motivated by the problem of the inequality of the principle of 'Tibak Rasul' between the previous generations of prophets and the present generation, which is in the anthology book of poetry Rumah-Mu Tumbuh di Hati Kami by Sosiawan Leak. The objectives of this study are (1) to find out how the representation of prophetic values in the poetry anthology entitled Rumah-Mu Tumbuh di Hati Kami by Sosiawan Leak, (2) to find out how it is implemented in learning Indonesian Language and Literature at Madrasah Aliyah. This study used a qualitative descriptive method, while the analysis applied was structuralism. The terms was described and analyzed using a prophetic literature review based on the theory presented by Kuntowijoyo in his book entitled Maklumat Sastra Prophetic. This type of research is library research. The primary data source used is the anthology book by Sosiawan Leak, entitled Rumahmu Tumbuh di Hati Kami. The data collection technique used was content analysis, namely listen, read, and take notes. The results of this study indicate that there are (1) prophetic values contained in the poetry anthology Rumah-Mu Tumbuh di Hati Kami, including humanization consisting of 4 data, transcendence of 7 data, and liberation of 2 data. (2) Implementation in learning Indonesian Language and Literature at Madrasah Aliyah.

Kata Kunci:
Nilai Kenabian;
Pembelajaran Bahasa dan
Sastra Indonesia;
Antologi Puisi.

Abstrak:

Penelitian ini dilatarbelakangi oleh adanya permasalahan ketimpangan prinsip 'Tibak Rasul' antara generasi nabi terdahulu dengan generasi zaman sekarang yang ada dalam buku antologi puisi Rumah-Mu Tumbuh di Hati Kami karya Sosiawan Leak. Tujuan penelitian ini ada dua yaitu (1) untuk mendeskripsikan bagaimana representasi nilai kenabian dalam antologi puisi bertajuk Rumah-Mu Tumbuh di Hati Kami karya Sosiawan Leak, (2) untuk mendeskripsikan bagaimana implementasinya dalam pembelajaran Bahasa dan Sastra Indonesia di Madrasah Aliyah. Penelitian ini menggunakan metode deskriptif kualitatif, sedangkan pisau analisis yang diterapkan adalah strukturalisme. Makna tersebut kemudian dideskripsikan dan dianalisis dengan menggunakan tinjauan sastra profetik berdasarkan teori yang dipaparkan oleh Kuntowijoyo dalam bukunya yang berjudul Maklumat Sastra Profetik. Jenis penelitian ini adalah library research. Sumber data primer yang digunakan adalah buku antologi karya Sosiawan Leak yang berjudul RumahMu Tumbuh di Hati Kami. Teknik pengumpulan data yang digunakan adalah simak, baca, dan catat. Hasil penelitian ini menunjukkan bahwa terdapat dua temuan yaitu (1) Nilai kenabian 
yang terdapat dalam antologi puisi Rumah-Mu Tumbuh di Hati Kami, diantaranya adalah humanisasi yang terdiri dari 4 data, transendensi 7 data, dan liberasi 2 data. (2) Implementasi dalam pembelajaran Bahasa dan Sastra Indonesia di Madrasah Aliyah.

Terkirim : 3 Juni 2021 ; Revisi: 18 September $2021 \quad$; Diterima: 28 Januari 2022

(CGhâncaran: Jurnal Pendidikan Bahasa dan Sastra Indonesia

Tadris Bahasa Indonesia

Institut Agama Islam Negeri Madura, Indonesia

\section{PENDAHULUAN}

Karya sastra merupakan bentuk ekspresi diri manusia berupa pemikiran, ide, gagasan, pengalaman hingga perasaan yang dituangkan dalam bentuk imajinatif. Menurut Inderasari (2017: 24) sastra dipandang sebagai sesuatu yang dinikmati, dihasilkan serta disajikan dengan berbagai macam cara. Karya sastra dikatakan sebagai alternatif oleh penulis untuk mengutarakan kegelisahannya terhadap berbagai peristiwa. Menurut Hall (1997: 15) upaya penggunaan bahasa (languange) dalam menyampaikan segala sesuatu yang berarti dan bermakna (meaningfull) kepada orang lain menumbuhkan upaya representasi. Budaya tersebut menjelaskan hubungan representasi dengan identitas, regulasi, produksi dan konsumsi (Ilhamsyah, 2019: 75). Perputaran pola sirkuit budaya tersebut akan memunculkan makna-makna terhadap bentuk komunikasi verba maupun non-verba.

Salah satu jenis karya sastra yang menjadi karya populer dan untuk mengekspresikan makna representasi ialah puisi. Puisi memiliki prinsip licentia poetica sebagai wujud kebebasan dalam berekspresi. Melalui puisi siapapun bisa mengkritik kejadian sosial, ekonomi, budaya, politik, pendidikan bahkan religius menjadi tematema puisinya (Lestari and Dwi, 2020). Begitu banyak karya sastra yang mengedepankan konsep spiritual sebagai ide-ide gagasannya dalam berkarya. Religiusisme senantiasa melekat pada setiap insan di muka bumi ini. Puisi religius ialah puisi-puisi yang berkaitan dengan keagaamaan dan mampu merasuk dalam jiwa manusia (Aulia, 2016:316)

Bagi sastrawan berpuisi dengan tema religius adalah hal yang sangat lumrah, namun ada juga puisi religi yang dituliskan dengan tema kenabian dan kerasulan. Tentu bukan hal yang mudah untuk menyelesaikannya. Sebab penulis harus paham betul bagaimana sikap dan perilaku para nabi. Agama telah menjadi identitas, landasan moral, serta etika bagi laku manusia. Al-Qur'an telah menjadi panutan yang dapat mencakup dalam berbagai aspek kehidupan, termasuk dalam bidang pendidikan dan kesusastraan.

Dalam dunia sastra, puisi kenabian dan kerasulan disebut dengan sastra profetik. Menurut Budiharto \& Himam (n.d: 136.) istilah profetik yang dikemukakan oleh Kuntowijoyo dapat berorientasi pada ilmu sosial transformatif yang mengarah pada ilmu 
sosial profetik. Hal tersebut disoroti oleh Budiharto dalam tulisannya, memuat berbagai usulan perubahan berdasarkan cita-cita etik serta ranah profetik tertentu. Hal ini mendorong etika Islam sebagai pelaksana reorientasi pada ilmu pengetahuan yang menjadi bagian dari ilmu sosial.

Sastra profetik merupakan karya sastra yang bersandar pada sikap dan perilaku nabi dengan tujuan memperluas ruang batin serta menggugah rasa kemanusiaan dan ketuhanan (Kuntowijoyo, 2019). Kajian yang dilakukan terkait karya profetik tidak lepas dari peran, isi, manfaat, dan kandungan yang ada dalam suatu karya dan dapat diilhami secara bersama. Sastra profetik mengandung semangat transendental dan sufistik bersumber dari nilai kenabian (Efendi, 2020). Dialektika yang dikaji dalam sastra profetik merupakan kolaborasi dari dua dimensi yang berbeda, yaitu dimensi lingkungan sosial dan dimensi transendental ketuhanan (Triyanto, 2013: 214).

Sosiawan Leak, sastrawan kelahiran Solo, 23 September 1967 ini berhasil menembus batas dengan menciptakan antologi puisi yang bertema kenabian atau sastra profetik di tahun 2020, yang bertepatan dengan bulan suci Ramadan. Penyair bernama asli Sosiawan Budi Santoso hadir dengan bukunya yang bertajuk Rumah-Mu Tumbuh di Hati Kami. Buku tersebut menjadi mahakarya momentum sekaligus monumental. Puisi-puisi tersebut didedikasikan untuk masyarakat sebagai bentuk kontribusinya terhadap lingkungan yang tengah dihadapkan dengan penyakit mematikan Korona saat bulan Ramadan. Korona ialah virus ganas yang berasal dari Wuhan, Cina. Buku tersebut mengungkap keresahan masyarakat terhadap wabah korona yang menjangkit bangsa Indonesia. Ketakutan tersebut semakin menjarah akibat dampak yang ditimbulkan tidak hanya di bidang kesehatan, sosial, ekonomi, budaya, tetapi juga pendidikan dan mengganggu ibadah umat muslim. Terlebih lagi saat bulan ramadan, ibadah puasa tidak lagi sama dengan tahun-tahun sebelumnya. Tidak ada salat tarawih, ngabuburit, buka bersama, pesta petasan selepas sahur, dan tadarus di masjid hingga larut malam. Semuanya diringkas dan direpresentasikan menjadi sebuah karya.

Dalam puisi-puisi tersebut, Sosiawan Leak mengungkap betapa ironinya kemanusian zaman sekarang yang begitu jauh dengan kebiasaan para nabi dalam beribadah khususnya dalam hal berpuasa. Sehebat apapun cobaan yang dihadapkan kepada nabi dan rasul tidak pernah menggugurkan niat ibadahnya sedikitpun. Hal ini dituliskan oleh Sosiawan Leak sebagai bentuk keprihatinannya terhadap sikap religius masyarakat saat ini. Seperti pada puisi berjudul Bisakah Puasa Kita episode 13. Ada yang tetap khusyuk berpuasa dalam berbagai himpitan, menjalankan ujian dengan 
penuh kesabaran dan keikhlasan. Begitu pula sebaliknya. Seperti yang dikatakan oleh Kuntowijoyo, sebagai umat muslim semestinya kita memerhatikan konsep Habluminallah Wa Hablumminnannas, antara Tuhan dan manusia haruslah tetap seimbang. Beribadah haruslah vertikal dan horizontal. Sosiawan Leak berhasil memaparkan semua dalam buku terbarunya.

Sastra religi dalam dunia pendidikan memiliki hubungan yang integral dengan filsafat pendidikan Islam (Inderasari, 2019: 131). Peran sastra religi dalam dunia pendidikan Islam dapat dijadikan sebagai sebuah acuan dalam tujuan maupun kegiatan belajar-mengajar. Penelitian ini dapat direfleksikan dalam pembelajaran bahasa dan sastra Indonesia pada kelas $X$ semester 2, KD 3.9 dan 4.9 yaitu mengidentifikasi informasi puisi dan menyimpulkan isi puisi. Pada kompetensi dasar tersebut, siswa dapat mendeskripsikan bagaimana amanat puisi dalam buku antologi Rumah-Mu Tumbuh di Hati Kami. Dalam menganalisa setiap unsur, siswa akan belajar mengenai banyak hal. Salah satunya ialah pesan moral spiritualisme yang mengarah pada pendidikan karakter siswa.

Hal ini dapat mendorong penguatan karakter siswa, sehingga siswa lebih mudah dalam menemukan jati dirinya. Urgensitas mengenai adab keagamaan siswa adalah tugas penting bagi setiap sekolah untuk memfasilitasi dalam pembelajaran. Nilai religius menjadi bagian dari 18 nilai pendidikan karakter yang dijadikan sebagai landasan sikap dan perilaku. Landasan tersebut menuntun siswa untuk memiliki karakter yang patuh dalam melaksanakan ajaran agama Islam (Wati \& Arif, 2017: 60). Oleh sebab itu, nilai religius menempati poin pertama pada kompetensi inti disetiap pembelajaran. Menurut Sulistyo (2014: 4) yang selaras dengan Organisasi Buruh Dunia atau ILO yang menerangkan bahwa nilai spiritual dan religius sangat dibutuhkan sebagai pijakan universal, karena berperan penting dalam menginspirasi serta membimbing pada tindakan manusia di masa mendatang dalam menghadapi era globalisasi.

Hal-hal tersebut yang menjadi alasan untuk mengaji buku ini dari segi spiritual yaitu nilai kenabian. Buku antologi puisi Rumah-Mu Tumbuh di Hati Kami sangat menarik untuk diteliti secara mendalam melalui kajian sastra profetik. Menurut Kuntowijoyo Sastra profetik memiliki etika profetik yang meliputi (1) humanisasi, (2) liberasi, (3) transendensi (Kuntowijoyo, 2019: 9). Kuntowijoyo (2019: 122) bahwa ketiga konsep tersebut terletak di gerak eksplorasi antara manusia terhadap tuhan. Sama halnya dengan sikap Khauf, iklas, beriman kepada hari akhir, ikhtiar, syukur, sabar, hingga kesederhanaan. 
Penelitian tentang sastra profetik pernah dilakukan oleh peneliti sebelumnya. Pertama, penelitian yang dilakukan oleh Asyifa (2018) dengan judul Nilai-nilai Pendidikan Profetik dalam Novel Surga Yang Tak Dirindukan Karya Asma Nadia. Hasil dari penelitian tersebut adalah nilai-nilai pendidikan profetik yang dikontekstualisasikan menjadi ketaqwaan, ikhsan, saleh sosial, saleh ritual, menjadikan doa sebagai sarana meminta pertolongan, sabar dan iklas dalam menjalani berbagai dinamika kehidupan, menjaga persaudaraan dalam heterogenitas dan menolak dehumanisasi. Penelitian ini sama-sama meneliti nilai pendidikan profetik yang mengarah pada pendidikan karakter. Meskipun sama-sama bidang literatur, tetapi memiliki objek penelitian yang berbeda. Penelitian ini menggunakan objek buku Rumah-Mu Tumbuh di Hati Kami karya Sosiawan Leak, sedangkan penelitian terdahulu menggunakan objek novel milik Asma Nadia berjudul Surga Yang Tak Dirindukan.

Kedua, penelitian Septia, Marni, \& Armet (2019) yang berjudul Representasi Nilai Religi dan Kepengarangan Puisi-puisi Karya Taufik Ismail. Penelitian ini sama-sama merepresentasikan nilai religius dengan teori sastra profetik milik Kuntowijoyo. Penelitian ini menggunakan objek puisi karya Sosiawan Leak, sedangkan penelitian sebelumnya menggunakan puisi karya Taufik Ismail. Pada penelitian sebelumnya terdapat analisis mengenai kepengarangan Taufik Ismail dalam membuat sebuah karya, sedangkan dalam penelitian mengenai kritik sosial yang relevansi dengan pembelajaran puisi di sekolah.

Ketiga, penelitian oleh Efendi (2011) dengan judul Pembelajaran Sastra Profetik Sebagai Media Pengembangan Karakter Siswa. Penelitian tersebut mengkaji terkait pentingnya sastra profetik bagi penanaman pendidikan karakter pada siswa. Dalam penelitian tersebut, Anwar Efendi menggunakan puisi-puisi religius yang memiliki unsurunsur sastra profetik. Sama seperti penelitian ini, Efendi menggunakan teori sastra profetik milik Kuntowijoyo.

Penelitian ini akan mengkaji terkait dengan puisi-puisi yang mengandung unsur etika sastra profetik, dengan harapan tercapainya tujuan penelitian yaitu merepresentasikan nilai kenabian dalam antologi puisi karya Sosiawan Leak. Penelitian ini penting dilakukan untuk menumpuhkan karakter peserta didik melalui pembelajaran puisi bertema profetik.

\section{METODE}

Penelitian ini merupakan penelitian kualitatif library research yang diuraikan secara deskriptif. Penelitian ini menggunakan dimensi sastra profetik yang meliputi (1) 
humanisasi, (2) liberasi, (3) transendensi (Kuntowijoyo, 2019: 9). Penelitian ini terfokus pada dimensi sosial dan transendental yang kemudian dikerucutkan menjadi elemenelemen pembentuknya. Pengklasifikasian elemen tersebut merupakan cara efektif untuk menganalisis unsur-unsur bahasa yang digunakan oleh penyair, sehingga peneliti dapat lebih mudah memaknai maksud setiap puisi.

Sumber data penelitian ini merupakan antologi puisi karya Sosiawan Leak dengan judul Rumah-Mu Tumbuh di Hati Kami yang diterbitkan oleh Elmatera pada bulan Juni 2020 (Leak, 2020). Buku tersebut memiliki 96 halaman dengan 30 episode puisi. Buku ini merupakan pembuktian dari tagar "Di rumah saja" yang diterapkan oleh pemerintah selama Ramadan Pandemi berlangsung. Teknik pengumpulan datanya dg konten analisis yg meliputi simak, baca, dan catat. Data-data penelitian berupa kata, kalimat, dan bait puisi yang diklasifikasikan dan dianalisis secara selektif berdasarkan kajian sastra profetik.

\section{HASIL DAN PEMBAHASAN}

Menurut Kuntowijoyo (2019: 02) sastra profetik merupakan sastra dialektik yang senantiasa berhadapan dengan realitas sosial yang ada. Sastra ini juga dinilai sebagai sebuah kajian yang memberikan penilaian dan kritik terhadap sosial-budaya di masyarakat. Sastra ini tergolong sebagai sebuah ilmu yang terlibat dalam sejarah kemanusiaan. Oleh karena itu, data yang dianalisis memiliki hubungan timbal balik terhadap kehidupan manusia, baik itu perilaku, sifat, peran, keadaan, bahkan aktivitas perasaan yang melibatkan agama.

\section{Humanisasi}

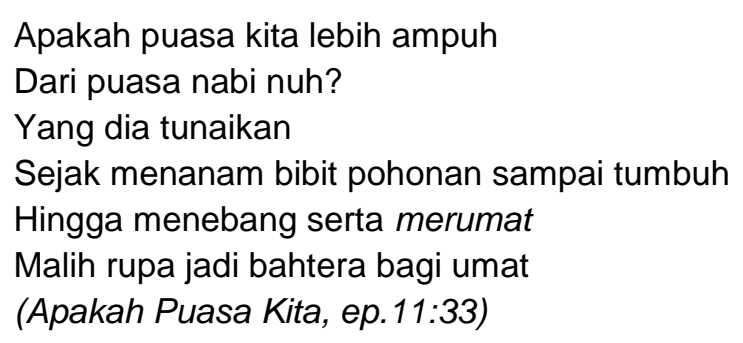

Sajak puisi dalam bait ketiga tersebut memuat pesan bagi para pembaca untuk saling memberi manfaat bagi sekitarnya. Penyair menyampaikan dengan begitu lugas. Beliau memberikan gambaran peristiwa Nabi Nuh yang merawat bibit pohon hingga tumbuh menjadi batang kayu yang dapat dimanfaatkan bagi umat manusia. Nabi Nuh AS merupakan salah satu nabi yang diberikan gelar khusus dari Allah SWT sebagai nabi yang tabah dan sabar dalam menyebarkan dakwah serta menghadapi segala 
bentuk pembangkangan dari kaumnya. Berkat kesabarannya itulah, Nabi Nuh AS berhasil menanam pepohonan sampai tumbuh menjadi pohon yang begitu besar. Setelah dirasa kuat, pohon-pohon tersebut ditebang dan dirakitnya menjadi kapal yang begitu besar. Kapal tersebut terdiri dari tiga lantai dengan panjang mencapai 200 meter. Kapal itu dirakit oleh Nabi Nuh AS di tengah gurun pasir yang tandus.

Dalam kutipan puisi tersebut, penyair menyisipkan pesan kepada pembaca agar mereka saling bersabar. Selain itu, tergambar begitu nyata dalam baris puisi terakhir Malih rupa jadi bahtera bagi umat. Batang pohon yang dirakitnya menjadi kapal itu membawa manfaat luar biasa bagi kaumnya. Tatkala Allah SWT menumpahkan air bah yang begitu dahsyat, kapal tersebut menjadi satu-satunya tempat berlindung yang paling aman bagi kaum Nabi Nuh AS. Hal tersebut mencerminkan betapa kesabaran Nabi Nuh AS sangat memberikan kebermanfaatan bagi kaumnya, sehingga mereka selamat dari peristiwa banjir besar yang terjadi hampir 6 bulan lamanya. Kaum Nabi Nuh AS yang tadinya mengucilkan dan meremehkan usaha Nabi Nuh AS, kini mengucapkan syukur dan terimakasih atas kerja kerasnya dalam menyelesaikan kapal tersebut.

Menurut Nasution \& Fahmi (2017: 214) manusia merupakan mikrokosmos dan makrokosmos yang senantiasa bergantung pada wujud Haq'Ta'ala. Humanisasi seringkali dihubungkan dengan perilaku-perilaku manusia dalam berbuat kebajikan terhadap sesama. Dalam ajaran Islam, pernyataan ini disebut sebagai amar ma'ruf yang artinya menyuruh pada kebaikan. Hal ini erat dengan upaya kebermanfaatan setiap manusia bagi manusia lainnya. Seperti pada puisi yang dituliskan oleh Sosiawan Leak dalam bukunya Rumah-Mu Tumbuh di Hati Kami yang berjudul Apakah Puasa Kita.

\author{
Zaid \\ Yang berhati baik \\ Bertabiat mulia \\ Serta berwatak dermawan \\ Kerap mengawal rasul ke medan perang \\ Dia juga sedia \\ Memuliakan tamu sepenuh jiwa \\ (Zaid Bin Tsabita Berhati Baik, ep.22:69)
}

Kutipan bait puisi di atas merupakan puisi episode 22 yang berjudul Zaid Bin Tsabit Berhati Baik. Dalam puisi tersebut penyair ingin menyampaikan pesan-pesannya kepada pembaca. Beliau memaparkan satu hal yang menjadi ketimpangan sosial terkait dengan empati dan simpati kepada sesama. Hal ini dipaparkan oleh Sosiawan Leak 
Agus Tika Dwi Savira, Siti Isnaniah

dengan mencontohkan sikap Zaid Bin Tsabit yang berhati mulia dan berwatak dermawan. Penyair mempertegas pesannya pada bait puisi berikutnya, yakni bait puisi ke-4.

\footnotetext{
Saat seorang musafir, ahli puasa

Tanpa bekal mampir ke rumahnya

Ditiupnya lampu hingga gulita

Kala tiba waktu berbuka

Bersama sang istri

la mengecap-ngecap udara hampa

Sementara makanan

Cuma terhidang di tangan tamunya
}

Menurut Nofiaturrahmah (2017: 322) sedekah atau shadaqoh adalah segala sesuatu yang diberikan kepada sesama muslim maupun non-muslim yang dilakukan dengan penuh kerelaan hati tanpa adanya batasan jumlah maupun waktu. Tergambar begitu nyata bagaimana Zaid Bin Tsabit sangat dermawan dengan memuliakan tamunya. Bahkan, tamu yang ia beri makanan berbuka tersebut bukanlah orang dari kaumnya, melainkan musafir yang sedang berpuasa tanpa bekal. Zaid beserta istrinya yang juga sedang berpuasa merelakan air susu yang mereka miliki untuk disuguhkan kepada tamunya, sedangkan mereka berdua rela berbuka dengan seteguk air putih saja. Peristiwa yang dikisahkan oleh penyair memiliki maksud yang begitu mendalam. Terlebih lagi, Sosiawan Leak menuliskan puisi tersebut diwaktu puasa. Tergambar nyata bahwa beliau berharap agar pembaca memperbanyak sedekah. Tidak hanya ketika lapang, tetapi juga ketika sempit. Seperti yang diriwayatkan oleh nabi dan rasul, tidak akan pernah merasa kekurangan bahkan jatuh miskin bagi umat yang senang bersedekah.

Bersedekah menjadi salah satu bentuk rasa syukur manusia kepada Tuhan semesta alam. Islam memerintahkan hambanya untuk senantiasa bersedekah baik secara terang-terangan maupun tersembunyi (Sangidu, 2008: 04). Bersedekah tidak melulu soal harta maupun uang, tetapi bisa dengan apa saja yang kita miliki. Jika dianugerahkan tubuh yang sehat, maka kita dapat bersedekah dengan raga kita, misalnya membantu orang lain. Apabila dirasa raga kita sudah tidak mampu, maka sedekah senyum menjadi amalan ringan namun berat pada timbangan kebaikannya. Seperti yang dituliskan oleh penyair dalam puisi episode 21 dengan judul Si Kurus Fakir yang Diridai.

Beruntunglah Abdullah bin masud

Meski mungil tubuhnya 
Oleh kekasih ilahi dibesarkan hatinya

Agar ia senantiasa ceria

Tak henti-henti menatahkan senyuman di wajahnya

Terutama ketika puasa

(Si Kurus Fakir yang Diridai, ep.21:66)

Puisi tersebut memaparkan betapa nabi sangat menyukai orang-orang yang murah senyum. Bahkan banyak ulama yang mengatakan bahwa senyum adalah sedekah terbaik bagi saudara kita. Sahabat nabi yang bernama Abdullah Bin Masud menjadi salah satu hamba Allah yang dikarunia kemurahan senyum di wajahnya. Gambaran senyum Abdullah Bin Masud mampu membuat siapa saja yang melihatnya merasa gembira dan senang. Betapa sejuk wajah-wajah orang mukmin yang senantiasa menebar senyum kepada saudaranya. Terlebih ketika sedang berpuasa. Menebar senyum dapat mengalirkan pahala dan memberatkan timbangan amal baik, bahkan menjadi amalan jariyah.

\footnotetext{
Yang karenanya

Manusia kembali terjaga

Menjaga kebersihan diri, keluarga,

Sesama hingga sedunia

(Anugerah Itu Nyata, ep.25:78)
}

Puisi di atas adalah kutipan bait episode 25 dengan judul Anugerah Itu Nyata. Puisi tersebut merupakan salah satu bentuk anugerah penyair dan pembaca atas segala yang dikaruniakan sang pencipta sampai dengan hari ini. Sosiawan Leak menuliskan puisi tersebut pada tahun 2020 bertepatan dengan merebaknya virus corona (covid-19). Tema-tema puisi yang beliau tuliskan berdasarkan situasi yang terjadi disekitarnya. Beliau mengamati betul bagaimana lingkungannya mencoba bertahan di bulan suci ramadan dengan melawan virus-virus tak kasat mata itu.

Purwanti (2017: 17) mengatakan bahwa menjaga lingkungan merupakan upaya untuk mendorong kebiasaan-kebiasaan baik yaitu peduli terhadap sesama, tidak merusak, melindungi lingkungan dan sesama, memupuk kepekaan, serta bertanggung jawab terhadap diri sendiri maupun lingkungan. Sebagaimana yang dipaparkan oleh Kuntowijoyo, bahwa beribadah haruslah seimbang vertikal dan horizontal. Tidak hanya menjaga hubungan kita dengan Tuhan, tetapi juga hubungan sesama manusia. Maka, dengan saling menjaga satu sama lain telah menjadi wujud kebajikan yang dinilai sebagai ibadah dan tercatat nilai pahalanya. Melalui tulisannya, Sosiawan Leak menyampaikan pesan moral untuk saling menjaga, melindungi, serta menjalin tali silaturahmi dengan sesama umat di muka bumi ini. 


\section{Transendensi}

Transendensi berasal dari bahasa latin transcendere yang berarti melampaui. Transendensi merupakan sebuah ilmu mengenai berbagai hal yang berhubungan dengan nilai-nilai ketuhanan. Menurut Kuntowijoyo (2019: 23) dalam Islam konsep transendensi meliputi khauf (rasa takut), raja' (sangat berharap), tawakal (pasrah), qana'ah (menerima pemberian Tuhan), syukur, ikhlas.

\footnotetext{
Ramadan hadir

Beragam rasa mengalir

Ada yang suka cita

Ada yang khusyuk memburu makna

Atau sibuk menimbang bakal pahala

Ada pula yang waswas dan cemas

Akankah sampai di akhir tujuan

Atau terpelanting dalam kesia-siaan

(Ramadan yang Bersemayam, ep.1:2)
}

Khauf atau perasaan takut merupakan sesuatu yang wajar dirasakan oleh setiap orang di muka bumi ini. Baik itu rasa takut terhadap hal-hal yang mencelakakan atau terhadap masa depan yang belum diketahui sekalipun. Kutipan puisi episode 1 dengan judul Ramadan yang Bersemayam menggambarkan kecemasan seorang hamba akan masa depannya. Bulan suci ramadan adalah bulan kemuliaan yang penuh berkah serta rahmat dari Allah SWT. Semua umat muslim menyambut kedatangannya dengan sikap yang berbeda-beda. Ada yang menyambutnya dengan riang gembira karena semakin dekat dengan hari raya, ada yang menyambutnya dengan mempersiapkan semua bekal menuju hari-hari puasa, ada yang menyambutnya dengan kecemasan akankah ia sampai pada bulan tersebut atau justru malah terpelanting dari bulan ramadan, ada juga yang hanya menunggu bulan itu tiba tanpa bekal apa-apa.

\footnotetext{
Puasa, menyeru diri

Mengaji

Tentang yakin dan ikhlas hati

(Laku Puasa, ep.3:8)
}

Kutipan bait puisi episode 3 dengan judul Laku Puasa menjadi salah satu puisi transendensi Hablumminallah, yaitu hubungan kepada tuhan semesta alam. Dalam puisi tersebut terdapat pesan spiritual bagi pembaca. Melalui puisi berkonsep puasa di bulan ramadan pandemi, penyair mengajarkan banyak hal. Salah satunya ialah tentang arti sebuah keikhlasan. Ikhlas merupakan sifat terpuji dalam ajaran agama Islam. 
Beberapa ulama menyebutkan bahwa sifat ikhlas merupakan puncak dari sebuah keimanan seorang hamba Allah.

Ikhlas merupakan perbuatan tulus yang akan menimbulkan banyak energi positif bagi pelakunya. Melalui ikhlas seorang hamba akan merasakan ketenangan dan ketentraman hati yang haqiqi dari Allah SWT. Selain itu, dari ikhlas terciptalah dimensi lain yang akan membawa seseorang pada kebajikan lainnya. Seperti tanggung jawab, sikap disiplin, sabra yang luas, rendah hati, serta bentuk ketaatan lain dalam beribadah. Sebab segala sesuatu yang dilandasi dengan keikhlasan akan dinilai sebagai bentuk ibadah yang utuh tanpa cacat sedikitpun.

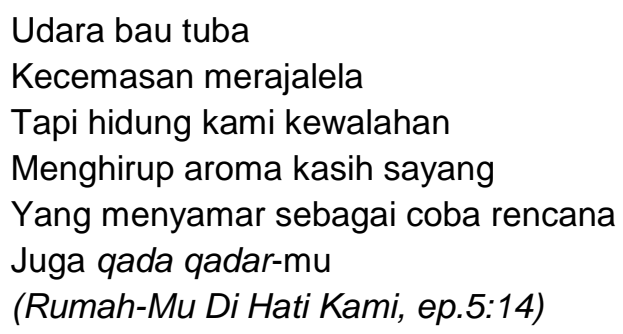

Setiap larik puisi menyimpulkan rasa syukur atas berbagai bentuk takdir yang dihadirkan oleh Allah SWT. Ramadan pandemi diyakini sebagai ketetapan Allah SWT melalui cara yang berbeda. Hal ini tergambar pada larik puisi pertama dan kedua, udara bau tuba//kecemasan merajalela. Larik tersebut mengisyaratkan kecemasan yang dirasakan oleh masyarakat akan adanya virus corona yang diberitakan dapat menular melalui udara. Sedangkan sumber oksigen manusia akan senantiasa membaur bersamaan dengan udara yang ada disekitarnya. Meskipun demikian, penyair menegaskan bahwa semua yang terjadi saat ini ialah murni bentuk kasih sayang dari Allah SWT, agar manusia bersyukur.

Sebagai umat muslim yang menganut sunnah Nabi dan Rasul, wajib hukumnya untuk selalu berprasangka baik terhadap ujian yang diturunkan Allah. Yang menyamar sebagai coba rencana/Juga qada qadar-mu. Qada qadar merupakan ketentuan serta ketetapan yang diberikan oleh Tuhan Allah SWT. Siapapun yang mengimaninya tentu mereka akan tetap berpegang teguh pada nilai-nilai kebaikan dan senantiasa percaya bahwa ujian inilah yang akan meningkatkan kualitas dirinya.

Sikap ikhtiar atau berusaha merupakan salah satu kewajiban yang harus dilaksanakan oleh seluruh hamba Allah SWT di muka bumi ini. Sebagaimana Rasulullah SAW yang senantiasa memberikan suri tauladan kepada ummatnya. "Bangunlah di pagi hari untuk mencari rezekimu dan melakukan tugasmu, karena hal itu membawa berkah dan kesuksesan (keberuntungan) (HR. At-Thabrani). Hadist tersebut 
Agus Tika Dwi Savira, Siti Isnaniah

diriwayatkan oleh Nabi Muhammad SAW agar manusia menyeru di jalan Allah dan senantiasa berikhtiar agar diridhoi urusannya. Seperti pada puisi episode 16 yang berjudul Siapa.

\author{
Beliaulah dia \\ Yang berpuasa serta menghiasinya \\ Dengan aneka amalan \\ Sejak fajar, siang hingga malam \\ (Siapa, ep.16:51)
}

Dalam kutipan bait puisi tersebut, digambarkan bahwa para nabi tidak pernah putus dalam berikhtiar menggapai keridhoan Allah SWT. Meskipun mereka sudah dijamin masuk surga, namun tetap berusaha untuk menunaikan amalan-amalan yang mendekatkan diri kepada Allah SWT. Yang berpuasa serta menghiasinya//Dengan aneka amalan, bahkan para nabi tetap menjalankan ibadah puasa penuh di bulan ramadan. Tidak hanya itu, mereka senantiasa melengkapi ibadahnya dengan amalanamalan lain.

Sama seperti manusia, nabi juga memiliki berbagai macam aktivitas yang harus dikerjakan mulai dini hari hingga malam tiba. Dalam puisi tersebut, penyair memberikan contoh Nabi Nuh yang berpuasa kala menanam bibit pohon hingga menjadi kapal penolong kaumnya, Nabi Musa yang tetap berpuasa saat menanti firman Allah SWT, hingga Nabi Ibrahim yang berpuasa disaat dirinya hendak dibakar hidup-hidup. Para nabi senantiasa berikhtiar, menjalankan kewajiban serta meninggalkan kebatilan demi keridhoan Tuhan Allah SWT. Puisi tersebut kemudian di akhiri dengan pertanyaan yang membawa pembaca untuk senantiasa bercermin pada amalan-amalan nabi.

Selain itu, penyair juga menuliskan sajak mengenai ikhtiar kepada Allah SWT pada puisi yang berjudul Mengakhirkan Sahur. Puisi episode 8 ini mengisahkan tentang seorang hamba yang berikhtiar dalam menunaikan ibadah puasa.

\footnotetext{
Mengakhirkan sahur di ujung

Serupa sabar menanak waktu

Meniriskan kusut dan debu

Perlahan mematangkan dandanan

Demi sempurnanya penampilan

Teliti merapikan wajah dan badan

Serta merumat niat, menata jiwa raga

Jadi untaian kata-kata istimewa

Agar tak kecewa sang kekasih

Saat bersimuka

(Mengakhirkan Sahur, ep.8:24)
} 
Dalam kutipan bait puisi tersebut, penyair menganalogikan puasa sebagai kekasih hatinya. Puasa dikonotasikan sebagai sesuatu yang begitu istimewa layaknya sang pujaan hati. Seperti yang kita ketahui, mengakhirkan sahur merupakan salah satu sunnah serta anjuran nabi SAW bagi umat muslim yang berpuasa. Mengakhirkan sahur artinya mengulur waktu untuk bertemu sang kekasih hati yaitu puasa. Penyair menggambarkan dengan begitu detail dalam bait tersebut.

/meniriskan kusut dan debu/ merupakan penganalogian penyair dalam menggambarkan dosa-dosa manusia yang berguguran sedikit demi sedikit dengan menunaikan ibadah puasa. Bahkan diriwayatkan oleh nabi SAW, bahwa tidurnya orang yang berpuasa adalah ibadah yang terhitung sebagai pahala disisi Allah SWT. Artinya, segala bentuk aktivitas baik yang dilakukan ketika sedang berpuasa akan tercatat sebagai amalan kebajikan yang mendatangkan rahmat Allah SWT. /Perlahan mematangkan dandanan/Demi sempurnanya penampilan// sahur menjadi bekal untuk menjalankan aktivitas sehari-hari dengan penuh semangat dan energi. Akan tetapi, Nabi Muhammad pun meriwayatkan bahwa sahur adalah kunci keberkahan dalam berpuasa. Namun, akan mencapai kesempurnaan ibadah untuk mereka yang bangun dan menikmati hidangan sahur sebelum masuk waktu subuh. /merumat niat, menata jiwa raga/ merumat dalam Bahasa Jawa memiliki arti merawat.

\footnotetext{
Bisakah puasa kita

Sekhusyuk puasa nabi ayub?

Yang kala kaya raya; berpuasa

Sehat, makmur, dan sentosa; berpuasa

Hingga ketika miskin papa serta didera derita

; tetap setia berpuasa

(Bisakah Puasa Kita, ep.13:39)
}

Bait puisi di atas adalah kutipan puisi episode 13 yang bertajuk Bisakah Puasa Kita. Puisi tersebut memuat nasihat bagi para pembaca agar senantiasa mengingat Allah kapan dan dimana pun. Melalui puisi tersebut, Sosiawan Leak berpesan agar manusia tidak melupakan Allah SWT. Mengingat Allah merupakan salah satu bentuk keimanan dan ketaqwaan sebagai hamba yang solih. Selain itu, dengan mengingat-Nya kita akan lebih mudah untuk mensyukuri hal-hal yang kita miliki.

Pergeseran zaman membuat orang semakin sibuk dengan pekerjaannya, keluarganya, dan dunianya masing-masing. Mereka lupa untuk mempersiapkan bekal menuju hari akhir. Dalam kutipan bait di atas, penyair memberikan contoh Nabi Ayub AS yang senantiasa bersyukur setiap waktu kepada Allah SWT. Yang kala kaya raya; berpuasa//Sehat, makmur, dan sentosa; berpuasa. Larik bait tersebut mengisahkan 
Nabi Ayub AS yang senantiasa menjalankan puasa sebagai bentuk rasa syukur kepada Allah SWT atas nikmat yang telah dikaruniakan. Beliau yang memiliki kecukupan harta tetap bersedia puasa untuk mensyukuri kehidupan. Memanjatkan syukur tidak hanya ketika kita sedang berkecukupan, tetapi juga ketika sedang merasa kekurangan. Seperti pada larik puisi berikut, Hingga ketika miskin papa serta didera derita//; tetap setia berpuasa. Bahkan ketika beliau jatuh miskin, tetap menunaikan ibadah puasa sebagai bentuk syukur kepada Allah SWT.

Jika kisah Nabi Ayub di atas mengajarkan untuk bersyukur dikala sempit dan sulit, maka kisah Nabi Yusuf berikut merupakan cerminan rasa syukur dikala berjaya. Memiliki kedudukan terhormat adalah ujian kenikmatan yang diberikan oleh Allah SWT kepada hamba pilihan-Nya. Seperti pada puisi episode 14 yang bertajuk Tetap Berpuasa; Untuk Apa?

\footnotetext{
Yusuf

Cerdas dan tampan

Alim, kaya raya, dan berkedudukan

Tetap puasa

Tak hanya tatkala dibuang ke sumur

Tanpa pakaian oleh saudara-saudaranya

Tetapi juga kala jadi pembesar negara

Dengan pangkat dan wewenang utama

(Tetap Berpuasa Untuk Apa?, ep.14:44)
}

Kutipan bait puisi tersebut mengisahkan kehidupan Nabi Yusuf yang penuh dengan keistimewaan. Beliau merupakan nabi yang paling tampan diantara nabi yang lainnya. Selain itu, Nabi Yusuf juga memiliki kekayaan yang berlimpah bahkan jabatan yang tinggi. Hal tersebut dituliskan oleh penyair dalam baris kedua dan ketiga, /Cerdas dan tampan/Alim, kaya raya, dan berkedudukan /tetap berpuasa/.

Hidup di akhir zaman seperti ini, banyak sekali manusia yang pandai mengingat Allah ketika mereka berada pada titik terbawahnya. Mereka senantiasa bersimpuh dan bersujud semakin lama menyebutkan apa-apa yang diinginkan. Mereka terus merayu dan mendekati penciptanya dengan harapan segera diwujudkan semua harapnya. Namun ketika doa-doanya diijabah dan diwujudkan satu per satu, banyak dari kita yang sering lalai. Manusia sangat mudah terlena dengan sedikit kenikmatan yang diberikan, sehingga mereka lupa bahwa semua yang didapat adalah dari Allah semata.

Listyandini, dkk. (2015: 474) menjelaskan bahwa sejatinya bersyukur merupakan bagian dari berterimakasih kepada Sang Khalik atas 'kecukupan' dan 'terpenuhinya' segala sesuatu. Dalam konteks ini, sudah semestinya kita menanamkan rasa syukur 
dikala sempit maupun lapang. Rasa syukur setiap insan dapat diwujudkan dalam berbagai macam bentuk sikap maupun tindakan. Dalam antologi puisi tersebut, penyair memberikan contoh sikap serta perilaku para nabi ketika mensyukuri hidup dengan berpuasa dan ibadah-ibadah lainnya.

Imam Ghazali menjelaskan bahwasanya sabar hanya dimiliki oleh manusia sebagai karunia dari Allah SWT yang menjadi keistimewaan dari makhluk lain di muka bumi ini (Gymnastiar, 2012: 10). Kesabaran merupakan salah satu sikap terpuji yang disenangi oleh Allah SWT. Sikap inilah yang akan mendorong seseorang untuk melakukan sesuatu dengan hati-hati, teliti, cermat, dan tentunya lebih baik.

Dalam puisi yang berjudul Mungkinkah Puisi Kita pada episode 12, terdapat tanda kuasa Allah SWT mengenai arti sebuah sikap sabar.

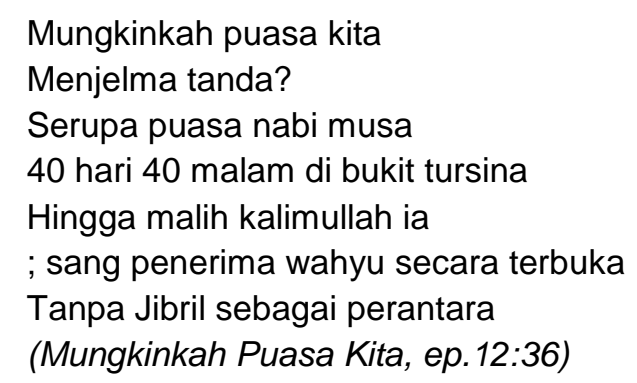

Penyair memberikan salah satu contoh peristiwa Nabi Musa AS yang berpuasa selama 40 hari 40 malam saat menanti wahyu dari Allah SWT. Berkat kesabarannya itulah, Allah memberikan wahyu secara langsung tanpa perantara Malaikat Jibril. Hal inilah yang menyebabkan Nabi Musa AS menjadi nabi yang begitu istimewa, lantaran beliau bisa berbicara langsung dengan Allah SWT. Melalui peristiwa tersebut, Nabi Musa AS menyandang gelar sebagai kalimullah (orang yang bisa diajak berbicara langsung oleh Allah). Beliau diciptakan berbeda dengan nabi yang lainnya. Ketika Nabi Musa AS menerima wahyu, beliau bertanya kepada Allah SWT, apakah karena puasanya sehingga Allah berkenan untuk menemuinya. Kemudian Allah menjawab, "Sesungguhnya puasamu hanya untukmu, sebab puasa melatih diri dan mengekang hawa nafsumu." Berdasarkan peristiwa Nabi Musa AS, terbukti bahwa Allah sangat menyukai hambanya yang menahan diri dengan sabar.

Dimensi transendental selanjutnya tampak pada sikap sederhana. Takaran kesederhanaan bagi setiap orang tentu tidak bisa disamakan, hal ini berkenaan dengan kemajemukan masyarakat yang berbeda-beda. Menurut Arumsari (2018: 15) dalam penelitiannya terkait konseling individual, kesederhanaan merupakan sikap rendah hati, bijaksana, dan mampu mengendalikan diri dalam melaksanakan kodrat sebagai manusia. 
Sikap sederhana terlebih dahulu dicontohkan oleh para nabi dan rasul pada zamannya. Salah satunya ialah Nabi Muhammad SAW, nabi yang membawa manusia pada cahaya terang benderang. Meski hidup berkecukupan, beliau adalah salah satu cerminan kesederhanaan yang patut untuk diteladani umat manusia. Seperti yang dituliskan oleh Sosiawan Leak dalam puisi yang berjudul Pantaskah Kita episode 15.

\author{
Siapa \\ Yang biasa berbuka bersahaja \\ Hanya dengan seteguk air atau sebutir kurma \\ Demi mempersembahkan siam bagi sang khalik semata \\ Sembari terus mensyukuri segala rezeki yang tiba? \\ (Pantaskah Kita, ep.15:48)
}

Bait puisi tersebut menggambarkan betapa sederhananya Nabi Muhammad SAW ketika berbuka puasa. Meski hanya dengan seteguk air dan satu butir kurma, beliau tetap khusuk berpuasa demi mengaharap keridaan Allah SWT. /Hanya dengan seteguk air atau sebutir kurma/Demi mempersembahkan siam bagi sang khalik semata/, puasa Nabi Muhammad SAW merupakan puasa yang paling mulia. Beliau tidak mengindahkan santapan berbuka.

Pucuk pemimpin umat/Puncak panglima agama, rasul utama/Tetapi tetap khidmat menyantap kurma buruk// Nabi Muhammad SAW yang dikenal sebagai pemimpin para umat, seorang ahli surga, manusia istimewa, seorang panglima islam, bahkan rasul utama, tidak pernah merasa paling istimewa diantara yang lainnya. Beliau senantiasa menjadikan dirinya memiliki kedudukan yang sama dengan manusia lain. Ketika dihidangkan kurma paling buruk sekalipun, beliau tidak menolak. la tetap memakan kurma tersebut. Seperti yang kita ketahui, Nabi Muhammad merupakan sosok yang pandai dalam menjaga hati. Bahkan sahabat nabi pernah mengatakan bahwa Nabi Muhammad pernah memakan anggur yang begitu masam, namun beliau tidak menghina buah tersebut. Beliau menghabiskan anggur tersebut seorang diri, dengan tujuan agar anggur masam itu tidak dibeli atau dimakan oleh yang lainnya. Hal ini bertujuan demi menjaga perasaan si penjual dan sahabat-sahabatnya.

\title{
Liberasi
}

Liberasi dalam kajian sastra profetik umumnya memaparkan mengenai berbagai ketidakadilan yang bersifat secara internal. Penindasan internal itu dapat berupa penindasan terhadap rakyat, politik maupun ekonomi. Dalam kajian sastra profetik, liberasi bertujuan untuk membebaskan manusia dari segala bentuk penindasan dan ketidakadilan. 


\begin{abstract}
Meski cuma berjumpa ramadan 9 kali;
8 kali sepanjang 29 hari

Satu kali sepanjang 30 hari

Tapi adalah puasa kanjeng nabi

Yang 6 kali

Mengobarkan perang suci

Mengibarkan panji-panji rabi

Demi mengabarkan firman-firman-Nya nan murni

(Mengaji Puasa Kanjeng Nabi, ep.17:54)
\end{abstract}

Dalam kutipan puisi berjudul Mengaji Puasa Kanjeng Nabi pada episode 17, terdapat unsur pembebasan atau liberasi. Puisi yang diselesaikan pada 17 ramadan ini mengisahkan perjuangan Nabi Muhammad SAW dalam berdakwah. Dalam puisi tersebut penyair menuliskan sepenggal cerita perjalanan nabi yang hanya bertemu ramadan sebanyak 9 kali. Satu diantaranya adalah ketika nabi tengah berjuang meniti rahmat dari Allah SWT. Mengobarkan perang suci, perang suci yang dimaksud pada larik puisi ke enam ini ialah perang badar. Perang badar ditempuh oleh Nabi Muhammad SAW tepat pada 17 ramadan. Rupanya inilah yang dimaksud oleh penyair, mengapa beliau menuliskan puisi ini tepat pada 17 hari ramadan dan menempatkan sebagai puisi episode 17. Perang badar tercatat sebagai perang pertama dalam mempertahankan kejayaan islam.

Mengibarkan panji-panji rabi//Demi mengabarkan firman-firman-Nya nan murni. Seperti yang dituliskan penyair pada larik puisi ke tujuh dan delapan, perang badar merupakan perang kejayaan untuk mempertahankan dakwah Rasulullah SAW. Perang inilah yang menjadi pertimbangan berlanjut atau tidaknya dakwah nabi dalam menyebarkan agama islam. Hal ini beliau lakukan demi membebaskan kaum-kaum musyrik dan membawanya pada jalan terang yaitu islam. Peritiwa ini disebutkan dalam surah Ali-Imron ayat 123-126. Pembebasan yang dimaksud ialah membebaskan ummatnya dari kebodohan atas kurangnya ilmu yang dimiliki. Beliau menyampaikan firman Allah SWT berbekal sifat kenabiannya yang sidiq (benar), amanah (dapat dipercaya), tabligh (jujur), dan fatonah (cerdas). Setiap ilmu yang disampaikan olehnya merupakan kebenaran serta jalan terang dari Allah SWT. Sehingga peristiwa ini termasuk dalam upaya pembebasan (liberasi) umat dari kebatilan.

Hidup bersosial merupakan hakikat setiap manusia sebagai makhluk hidup. Menjalani kehidupan dengan rukun menjadi salah satu kunci dalam menciptakan lingkungan yang sejahtera. Hal ini disinggung oleh Sosiawan Leak dalam puisinya yang berjudul Bisakah Puasa Kita episode 13. 


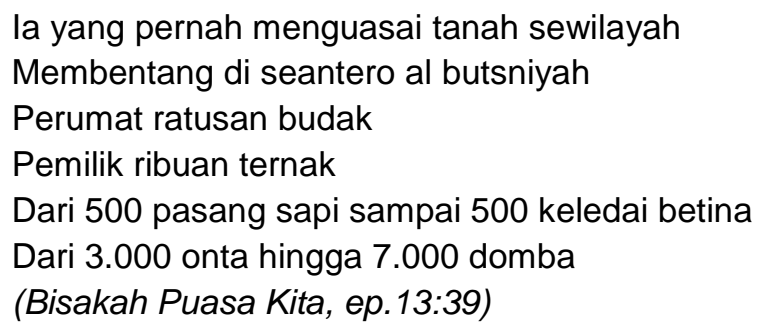

Berdasarkan kutipan puisi di atas, diceritakan Nabi Ayub AS yang memiliki kekayaan melimpah dan hidup dengan sejahtera. Beliau memiliki puluhan ribu ekor binatang ternak seperti keledai, sapi, onta dan domba. Meskipun demikian, Nabi Ayub AS tidak pernah menggunakan hartanya untuk kepentingan pribadi. la selalu memanfaatkan kekayaannya untuk mensejahterakan masyarakat di lingkungan sekitar tempat tinggalnya. Dalam perjalanan kisah hidup Nabi Ayub, beliau dikenal sebagai sosok yang sangat dermawan. Seperti yang dituliskan oleh penyair dalam larik puisi tersebut. Perumat ratusan budak//, beliau menghidupi ratusan budak yang kelaparan. Nabi Ayub dikenal sebagai nabi yang paling sabar dan iklas dalam bersedekah, baik dikala sempit maupun lapang. Bahkan ketika susah sekalipun, beliau rela mengorbankan hartanya demi berjuang dijalan islam. Sebagai manusia, sudah semestinya kita hidup berdampingan dengan rasa empati terhadap sesama. Selain pada puisi episode 13, Sosiawan Leak juga menuliskan terkait liberasi kemiskinan dalam puisi episode 2 yang berjudul Empati Puasa.

Kutipan puisi tersebut mengajarkan untuk bersikap Hablumminannas kepada manusia. Sikap empati terhadap sesama manusia menjadi kewajiban bagi siapapun yang mampu. Betapa banyak manusia yang hidup serba berkecukupan, namun justru digunakan untuk kesenangan dan kepentingan pribadinya. Mereka yang kaya raya, tidak jarang lupa untuk melihat ke bawah. Bahwa masih banyak orang yang membutuhkan uluran tangannya. Beliau menyampaikan dengan diksi-diksi yang bijaksana dan mudah dimengerti.

\section{Implementasi Dalam Pembelajaran Bahasa Indonesia di Madrasah Aliyah}

Puisi merupakan salah satu materi pembelajaran Bahasa Indonesia yang diajarkan mulai jenjang SD, SMP, hingga SMA. Di bangku SD materi puisi mulai dikenalkan melalui karya-karya sederhana bertema ibu, persahabatan, atau guru. $\mathrm{Di}$ jenjang SMP, puisi mulai dipelajari secara mendalam seperti unsur batin dan unsur fisik atau unsur intrinsik dan ekstrinsik. Dari sinilah siswa mulai diajak untuk berpikir kritis, mendalam, dan analitik. Pada tahap inilah siswa diajarkan untuk membedah sebuah 
karya sastra puisi. Hal tersebut dapat berupa unsur pembangun puisi hingga menemukan pesan di dalamnya. Amanat dalam puisi mengandung pesan moral yang dapat dijadikan sebagai contoh pembelajaran untuk siswa.

Nilai-nilai kenabian banyak sekali ditemukan dalam buku antologi puisi Rumah-Mu Tumbuh di Hati Kami. Berdasarkan klasifikasi data yang diperoleh dalam penelitian ini, puisi-puisi tersebut dapat diimplementasikan dalam pembelajaran Bahasa Indonesia KD 3.9 dan 4.9 yaitu mengidentifikasi informasi puisi dan menyimpulkan isi puisi. Siswa dapat menganalisis amanat atau pesan moral apa saja yang terkandung dalam setiap puisi pada buku tersebut. Melalui analisis amanat puisi, siswa dapat menyelaraskan dengan realitas sosial di lingkungannya. Siswa akan belajar membaca keadaan disekitarnya, hingga menganalogikan degradasi moral yang terjadi sekarang dengan zaman nabi terdahulu.

Begitu banyak karya sastra puisi atau buku kumpulan puisi yang mudah untuk diakses. Namun tidak semua teks puisi dapat digunakan sebagai bahan ajar mata pelajaran puisi. Sebagai seorang pendidik, sudah semestinya mampu memilih dan memilah bahan ajar yang tepat. Terlebih, materi yang dapat mendidik dan membentuk karakter siswa. Antologi puisi karya Sosiawan Leak yang bertajuk Rumah-Mu Tumbuh di Hati Kami merupakan salah satu buku yang tepat untuk menguatkan karakter siswa, khususnya nilai religius.

Dalam antologi puisi Rumah-Mu Tumbuh di Hati Kami terdapat banyak nilai moral/spiritual yang disampaikan. Nilai-nilai tersebut direpresentasikan dari realita sosial yang ada di masyarakat. Penyair mengisahkan beberapa peristiwa di zaman nabi terdahulu yang dapat membuka wawasan serta pengetahuan pembaca akan nilai religi. Hal tersebut juga dapat di implementasikan dalam pembelajaran Bahasa Indonesia. Misalnya pada puisi episode 13 yang bertajuk Bisakah Puasa Kita. Di dalamnya terdapat nilai-nilai religius yang dianalogikan dengan kisah Nabi Syuaib, Nabi Yunus, dan Nabi Ayub. Penyair mengawali sajak tersebut dengan satu kalimat tanya /Bisakah puasa kita/sekasab puasa nabi syuaib?/. Kalimat tanya tersebut dapat menggugah siswa untuk senantiasa bercermin pada ibadah para nabi yang dikisahkan di bait berikutnya.

Guru dapat mengajarkan apa arti usaha atau ikhtiar bagi manusia di muka bumi ini. Ikhtiar merupakan salah satu kewajiban setiap umat yang bernyawa tanpa terkecuali. Allah memerintahkan kepada seluruh makhluk hidup untuk berusaha memenuhi kehidupan dengan cara yang baik, lurus, dan diridai oleh-Nya. Hal tersebut dapat ditemukan dalam larik kedua pada diksi sekasab. Kata sekasab berasal dari 
Agus Tika Dwi Savira, Siti Isnaniah

istilah Bahasa Arab yang artinya berusaha. Penggunaan diksi tersebut dipilih oleh penyair untuk menerangkan kesalehan Nabi Syuaib. Beliau yang telah dijamin mendapat surga karena kesalehannya, tetap melaksakan ibadah-ibadah yang disenangi oleh Allah SWT. Ibadah yang dimaksudkan dalam bait tersebut adalah ibadah puasa yang menjadi bukti ketaqwaan Nabi Syuaib kala itu.

Pada bait ke enam, penyair menuliskan kisah Nabi Ayub AS dalam berpuasa. Beliau mengisahkan tentang kemakmuran serta kesengsaraan yang dialami oleh Nabi Ayub AS. Penyair menyuguhkan peristiwa pilu Nabi Ayub AS ketika diberi cobaan oleh Allah SWT. Nampak begitu jelas bagaimana Allah memberikan kenikmatan beriringan dengan cobaan. Melalui puisi tersebut dapat diambil hikmah bahwasanya beribadah harus tetap ditunaikan dalam keadaan suka maupun duka.

Melalui bait puisi tersebut, siswa dapat menganalisis makna tersurat dan tersirat yang terkandung dalam puisi. Kemudian, siswa juga dapat mengkorelasikan maknamakna tersebut dalam kehidupan sehari-hari. Dari pembelajaran tersebut siswa diajak untuk menyimak peristiwa yang terjadi di sekelilingnya dengan menghubungkan setiap makna puisi dengan yang terjadi di realita sosial.

\section{SIMPULAN}

Hasil penelitian ini berimplikasi terhadap pembelajaran bahasa dan sastra Indonesia. Nilai kenabian sastra profetik dalam novel Rumah-Mu Tumbuh di Hati Kami karya Sosiawan Leak sesuai untuk dijadikan bahan ajar pembelajaran Bahasa Indonesia, khususnya di Madrasah Aliyah. Pembelajaran tersebut sesuai dengan KD 3.9 dan 4.9 yaitu mengidentifikasi informasi puisi dan menyimpulkan isi puisi. Berdasarkan isi KD tersebut, antologi puisi karya Sosiawan Leak bertajuk Rumah-Mu Tumbuh di Hati Kami memuat pesan moral spiritual yang cukup memotivasi siswa. Nilai spiritualisme yang terkandung di dalam puisi-puisi tersebut dapat mendorong penguatan karakter bagi siswa. Pendidikan karakter merupakan aspek terpenting dari proses pembelajaran. Membangun karakter siswa dapat dilakukan dengan memberikan wawasan berupa bacaan yang berkualitas. Salah satunya melalui buku antologi puisi karya Sosiawan Leak yang bertajuk Rumah-Mu Tumbuh di Hati Kami.

\section{DAFTAR RUJUKAN}

Arumsari, C. (2018). "Konseling Individu dengan Teknik Modeling untuk Meningkatkan Kekuatan Karakter Kesederhanaan." Jurnal Konseling Indonesia, 4(1), 15.

Asyifa, A. N. (2018). Nilai-Nilai Pendidikan Profetik dalam Novel Surga Yang Tak Dirindukan Karya Asma Nadia Ayu Nur Asyifa.

Budiharto, S., and Himam, F. (n.d.). "Konturk Teoritis dan Pengukuran Kepemimpinan 
Profetik." Jurnal Psikologi, 33(2), 136.

Efendi, A. (2011). Pembelajaran Sastra Profetik sebagai Media Pengembangan Karakter Siswa. Jurnal Cakrawala Pendidikan, (2).

Efendi, A. N. (2020). KRITIK SASTRA: Pengantar Teori, Kritik, \& Pembelajarannya. Malang: Madza Publishers. Retrieved from http://repository.iainmadura.ac.id/id/eprint/255

Gymnastiar, A. (2012). "Indahnya Kesabaran.” Emqies Publishing.

Hall, S. (1997). "Representation: Cultural Representations and Practices." London: Sage Publications.

Ilhamsyah, M. R. (2019). "Representasi Muslimah Dalam Film "Assalamualaikum Calon Imam"(Tinjauan Teori Representasi Stuart Hall)". Surabaya.

Inderasari, E. (2017). "Experiental Learning Dalam Kemampuan Apresiasi Puisi Mahasiswa Tadris Bahasa Indonesia FITK IAIN Surakarta." Jurnal Kembara, 3(1), 24.

Inderasari, E. (2019). "Implementasi Kurikulum BIPA (Bahasa Indonesia Bagi Penutur Asing) Berbasis Cultural Islamic Studies (Integrated Curriculum) Di Perguruan Tinggi Islam." Lingua Scientia, 11(1), 131.

Kuntowijoyo. (2019). "Maklumat Sastra Profetik.” Yogyakarta: Divapress.

Leak, S. (2020). Rumah-Mu Tumbuh di Hati Kami. Yogyakarta: Elmatera .

Lestari, M. I., and Dwi, R. (2020). "Hubungan Minat Baca dan Kebiasaan Membaca Karya SastraTerhadap Kemampuan Menulis Puisi". Semantik, 20.

Listyandini, and Dkk. (2015). "Mengukur Rasa Syukur: Pengembangan Model Awal Skala Bersyukur Versi Indonesia." Jurnal Psikologi Ulayat, 2(2), 474.

Nasution, A., and Fahmi, I. (2017). "Humanisasi Pendidikan Islam Melalui Antropologi Transendental Hamzah Fansuri." Edukasia, 12(1), 214.

Nofiaturrahmah, F. (2017). "Penanaman Karakter Dermawan Melalui Sedekah." Ziswaf, $4(2), 322$.

Purwanti, D. (2017). "Pendidikan Karakter Peduli Lingkungan Dan Implementasinya." Dwijacendekia, 1(2), 17.

Sangidu, A. (2008). "Dahsyatnya Sedekah.” Tangerang: Qultum Media.

Septia, E., Marni, S., and Armet, A. (2019). Representasi Nilai Religi dan Kepengarangan Puisi-Puisi Karya Taufik Ismail. Poetika: Jurnal IImu Sastra, 7(1), 32-50.

Sulistyo, H. (2014). "Relevansi Nilai Religius Dalam Mencegah Perilaku Disfungsional Audit." Jurnal Ekonomi Manajemen Dan Akuntansi, (36), 4.

Triyanto, T. (2013). "Estetika Profetik Ahmad Tohari Dalam Khazanah Budaya Cablaka." Ibda', 11(2), 214.

Wati, D., and Arif, D. (2017). "Penanaman Nilai-nilai Religius di Sekolah Dasar Untuk Penguatan Jiwa Profetik Siswa." Yogyakarta: Prosiding Konferensi Nasional Kewarganegaraan III. 